\title{
Remembering and constructing Israelite identity in postexilic Yehud: Some remarks on the penitential prayer of Nehemiah 9:6-37
}

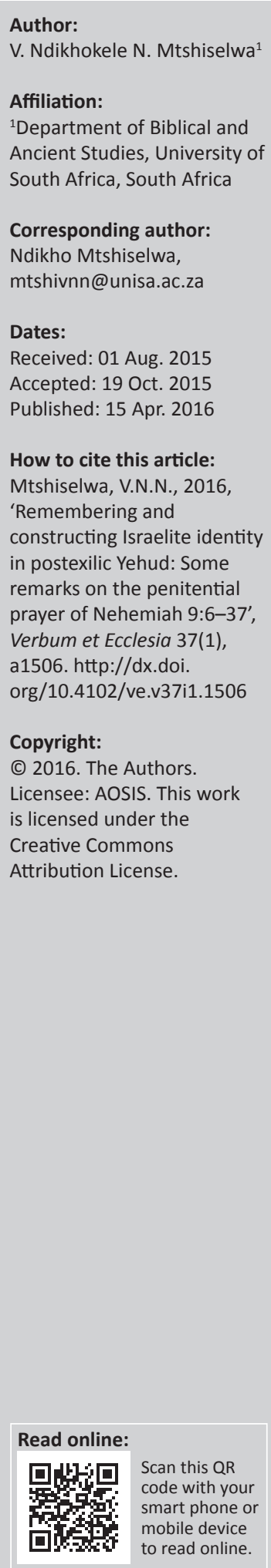

That there is a growing focus and elaboration of prayers in the Old Testament scholarship on the postexilic biblical writings suggests that such prayers received an authoritative status in postexilic Yehud. Firstly, this paper argues that not only did the remembrance of the story of Israel confer an authoritative status to Nehemiah 9:6-37, it also served the purpose of casting a hopeful and prophetic imagination of a liberated community in Yehud. Secondly, it is argued in this paper that the prayer of Nehemiah 9:6-37 shaped the identity of the Jews in Yehud amidst socio-economic injustices. This identity was linked to the patriarch Abraham (cf. Neh 9:7-8), to the liberation of the Jews from Pharaoh under the leadership of Moses (cf. Neh 9:9-15, 21), to the possession of the Promised Land (cf. Neh 9:22-25), to the caution about the consequence of disobedience to Yahweh - the exile (cf. Neh 9:16-21, 26-30)- and to the demise of the kingdom in the Babylonian exile (cf. Neh 9:31-37). On the whole, it is argued in this paper that the prayer of Nehemiah 9:6-37 was composed and transmitted with the view to remember and construct the identity of the Jews in postexilic Yehud.

Intradisciplinary and/or interdisciplinary implications: Not only does this article explore the religious aspect of Nehemiah 9:6-37, it equally investigates the socio-economic and political undertones in the text in order to determine the context from which the penitential prayer emerged. It is argued here that in the postexilic Yehud context, Nehemiah 9:6-37 served to remember and construct the identity of the Jews.

\section{Introduction}

On the issue of literary transmission of ancient biblical texts and the way such texts received an authoritative status, Fishbane (1985) argued:

The final process of canon formation, which meant the solidification of the biblical traditum and the onset of the post-biblical traditio, was thus a culmination of several related processes. Each transmission of received traditions utilized materials which were or became authoritative in this very process; and each interpretation and explication was made in the context of an authoritative traditum. Further, each solidification of the traditum was the canon in process of its formation; and each stage of canon formation was a new achievement in Gemeindebildung, in the formation of an integrated book-centred culture. (p. 18)

Drawing on Fishbane's argument, Venter (2002:470-488) has proposed that the formation of the biblical canon was enacted on different interactive levels in which an authoritative status was conferred to ancient texts. The first level is the canonical process of growth which was not restricted to mere quotations or recycling of existing phrases, but was also present at the 'higher' level of dialogue with older genres and existing ideological patterns (Venter 2002:470). The second interactive level is the inclusion and omission of existing materials in the agglomeration of material into an authoritative collection (Venter 2002:472). The third level is the revision, addition, compilation, and editing of the selected literature which was to be included or excluded in the final collection (Venter 2002:485). As Venter excellently perceived, the process of revision, addition, compilation, and editing of the selected literature was all in reaction to different social factors the socio-historical context (Venter 2002:485). Interestingly, the main point that both Fishbane and Venter make is this: in each transmission of received traditions, the authors and redactors used materials which were, or subsequently became, authoritative.

The debate on the way ancient texts received authoritative status adds a curious dimension to the study of prayers, and more specifically the penitential prayers in postexilic Yehud. This paper is not meant to investigate the literary transmission of the penitential prayer of Nehemiah 9:6-37 in its oral stage. Nor does it intend to focus on how the transmission of the prayer under consideration 
took its form from the written stage in the postexilic period to the present day version. There is a place for all that. However, this paper attempts to offer some remarks on the written stage of the transmission of Nehemiah 9:6-37. It will be argued that Nehemiah 9:6-37 was composed and transmitted with the view to remember and construct the identity of the Jews in postexilic Yehud. Based on academic literature, this paper concludes that the remembrance or the retelling of the story of Israel in Nehemiah 9:6-37 and the way the penitential prayer of Nehemiah 9:6-37 shaped the identity of the Jews in postexilic Yehud shed light on how the prayer received its authoritative status. With respect to the retelling of the story of Israel, this article will focus on selected prophetic undertones which include prophecies of doom and deliverance, reference to the work of the prophets, as well as to prophets, and allusions to the work of Moses who is partly viewed as a prophet. The discussion will follow the outline below:

- Retelling the story of Israel.

- Identity formation in postexilic Yehud.

\section{Retelling the story of Israel in the postexilic context}

In her discussion of the 'scripturalisation' of the penitential prayers in ancient Israel, Newman (1998:112-123) focuses on the representation of Israel's past, reference to the Torah, the canonisation of textual material, and to the scriptural reference to the past traditions embedded in the Pentateuch. Regarding the text of Nehemiah 9:6-37, she argues that 'an essential feature of the prayer's "scripturalization" is its representation of Israel's past' (Newman 1998:113). If the concept of 'scripturalisation' is related to the process of conferring an authoritative status to ancient stories of Israel, as I am inclined to believe, it may thus be argued that the penitential prayer of Nehemiah 9:6-37 received an authoritative status because it retold the story of Israel. As Newman (1999:61) excellently perceived, 'written traditions - and interpretive traditions have become the means by which the past is recalled'. Thus, a discussion on the way in which the author and redactor of Nehemiah 9:6-37 used older traditions and texts is in order.

\section{Confession of sins}

Drawing on both Throntveit (1992:100) and Venter's (2009:5) position on the Gattung of Nehemiah 9:6-37, the combination of the Gattungen as well as an element of the historical review presents the prayer as the confession of sins by the Israelites. From a form-critical point of view, Nehemiah 9:6-37 consists of:

a direct address to God in which an individual, a group, or an individual on behalf of a group confesses sins and petitions for forgiveness as an act of repentance. (Venter 2009:5; cf. Werline 2006:xv)

As it is generally accepted, the penitential prayer of Nehemiah 9:6-37 condemns the 'sins' of the ancestors of the Jews (Balentine 2006:17). In terms of the intertextuality of the preceding text, Werline (1998:62-64) has convincingly submitted that Nehemiah 9:6-37 has its roots in earlier texts, namely, Deuteronomy 4:29-30 and 30:1-10 (cf. Falk 2007:133134; Moffat 2013:91). Making a similar point as Werline, Balentine (2006:17) argues that the Deuteronomistic 'politics of penitence' adopted by the author of Nehemiah 9:6-37 aimed to articulate a confession of the sins of the ancestors of the Jews which were also manifested in the abuse of power during the period of the monarchy that imposed exile to the Jews (cf. Said 2000:184). Because of the tendency of abusing power by those in the position of authority, particularly by the agency of the Persian Empire, the Deuteronomistic 'politics of penitence' seem to have been relevant in postexilic Yehud. On this point, that the sins of the ancestors of the Jews are condemned in Nehemiah 9:6-37 appears to be an appealing view. Worthy of point is the view that certain texts of the Deuteronomistic Deuteronomy that partly emerged in the sixth century in the exilic period were reused in the postexilic period (cf. Dt 4:29-30 and 30:1-10; Otto 2013:2).

Although it is generally accepted that the author of Nehemiah 9:6-37 draws on Deuteronomy 4:29-30 and 29:21-30:10, the connections between these texts need to be teased out. Worthy of note is the relation of Nehemiah 9:6-37 to Deuteronomy 4:29-30 and 30:1-10, particularly in terms of the theological outlook of these texts. On the issue of exclusively serving YHWH, Nehemiah 9:6 recognises YHWH as the only deity that exists, while Deuteronomy 29:26 alludes to how the Jews worshiped other gods and Deuteronomy 4:28 refers to an instance where the Jews worshiped other gods. It certainly seems that Nehemiah 9:6 is responding to both the texts of Deuteronomy 29:26 and Deuteronomy 4:28 by contesting the worship of other gods. Furthermore, both the text of Deuteronomy 29:23 and 4:25 expresses the way YHWH is angry toward the sins of the Jews. However, surprisingly, Nehemiah 9:17 articulates the manner in which $\mathrm{YHWH}$ is slow to anger. Although at first glance one may see a contradiction, in the end it seems that the text of Nehemiah is providing a response to sins in which $\mathrm{YHWH}$ is slow in anger. Thus, it becomes clear that Nehemiah 9:6-37 is a direct reaction to both the text of Deuteronomy 29:23 and 4:25. However, the extent of YWHW's anger, namely, the scattering of the Jews among other nations as evident in both Deuteronomy 29:28 and 4:27, is not mentioned in Nehemiah 9:6-37, thus revealing a contrast between the penitential prayer of Nehemiah 9 and the Deuteronomistic texts. Furthermore, on the point of Jews being instructed to return to the Torah and subsequently YHWH, Nehemiah 9:29 is related to Deuteronomy 4:30 and 30:10.

Furthermore, the prophetic motives in the Book of Deuteronomy, specifically in chapters 4, 29-30 and 34, pointed out by both Nihan (2010:21-55) and Otto (2013:1-5), add an interesting aspect to the relation of Nehemiah 9:6-37 to Deuteronomy 4:29-30 and 29:21-30:10. As Nihan (2010:23) correctly argued, in the postexilic period of the fourth and fifth centuries, the figure of Moses was reinterpreted in prophetic terms because there would never again be a 
prophet like Moses (cf. Deut 34:10-12). Unlike Nihan, Otto (2013:2) argues that Moses acted as prophet, announcing the catastrophe of Israel and deliverance (cf. Deut 4:29-30). In the text of Deuteronomy 29 and 30, Moses is portrayed as articulating a prophecy of doom in exile and deliverance. Noteworthy, not only do Moses' prophecies of doom and deliverance presuppose the end of exile, as Otto (2013:2) rightly observed, they equally suggest that the postexilic redactor of the Pentateuch found it necessary to reiterate YHWH's position on sin. The use of Moses' prophecies of doom and deliverance in Deuteronomy 4:29-30 and 29:2130:10 by the author of Nehemiah 9:6-37 adds a prophetic dimension to the penitential prayer. Nehemiah 9 captures the prophecy of the doom and deliverance in vv. 26-30, because the author states that the Jews were warned against awful blasphemies (sins), but did not listen to the prophets. However, YHWH continued to deliver the Jews, enabling a reading of both the prophecy of doom and deliverance in some strata of Nehemiah 9:6-37. Thus, the view that the penitential prayer of Nehemiah 9:6-37 served to offer a prophetic imagination of a liberated (or delivered) community in the postexilic period may hold. This holds true, because the idea of deliverance is articulated in vv. 9-15, 27. That Nehemiah 9:37 reads: 'Its rich yield goes to the kings whom you have set over us because of our sins; they have power also over our bodies and over our livestock at their pleasure, and we are in great distress' supports the idea that the penitential prayer under consideration suggests the persistence of sin. Drawing on Deuteronomy 4:29-30 and 29:21-30:10, the author of Nehemiah 9:6-37 speaks against the sins of the Jews in postexilic Yehud, and even more purposefully, refers to the Torah.

\section{The rise of the Torah}

In his critique of the formation of the Torah, particular with regard to Deuteronomy 34:4 and 34:10-12, a text often linked to Nehemiah 9:6-37, Schmid (2007) holds that:

The process of 'theologizing' Moses is best explained by the desire to confer authoritative status to the Torah (for which 'Moses' stands). 'Moses' is placed in close connection to God, so that the Torah can lay claim to equivalent authority. (p. 242)

Put differently, not only does the theologising of Moses give the Torah an authoritative status, it also suggests that ancient texts which linked the Torah to Moses received an authoritative status. On this point, Moses is a 'normative character and teacher who vouches for the authority of the corpus of the Torah' (Brueggemann 2003:16). It becomes clear that the reference to the Torah in ancient texts conferred an authoritative status. Prior to the consideration of the allusions made to the Torah in Nehemiah 9:6-37, worthy of note is the interpretation of the Torah in Nehemiah 8. As Brueggemann (2003:367-368) argues, not only does the reference to the Torah in Nehemiah 8 restore the dignity of the Jews, it equally confers authority to the text. Also, it is argued that Nehemiah 8 introduces a unit in which Ezra's reading of the Torah (cf. Neh 8:1-12; 8:13-14; 9:3) is followed by a confession of $\sin$ (cf. Neh 9:6-37) and concluded by the firm agreement' of Nehemiah 10 (Clines 1989:202; Klein 2004:22). An interesting point, though, is made by Clines. He decisively argues that the Torah in Nehemiah 8-10 'becomes the directive of the people's actions' (Clines 1989:202). With respect to the penitential prayer of Nehemiah 9:6-37, it must be noted that $\mathrm{YHWH}$ is presented as the giver of the Torah (vv.13-14). In this instance, $\mathrm{YHWH}$ is portrayed as a speaker and the lawgiver, enabling the notion of divine law. In this case, the rise of the Torah in Nehemiah 9:6-37 (though not limited to this section) conferred an authoritative status to the penitential prayer under consideration because it provided a directive to the people's actions.

\section{Second Exodus}

That an allusion to the first 'captivity' of the Jews in Egypt is made in Nehemiah 9:9-11 is indisputable. This allusion has led Throntveit (1992:99) to propose a theme of a 'second exodus'. If one reads the retelling of the story of YHWH's deliverance of his people from Egypt (vv.9-15, 21) in the light of the portrayal of slavery - oppression - of the Jews in postexilic Yehud (vv.36-37), one may appreciate the theme of a 'second exodus' (cf. Williamson 2004:286). The theme stands in continuity with the Exodus tradition. Regarding Nehemiah 9:9, the suffering of the Jews in Egypt (cf. Exod 3:7; Deut 26:7) is linked to the crisis at the Red Sea (cf. Exod 14:10, 15a) to describe YHWH's response to the predicament of the Jews (Boda 1999:117).

Additionally, the prophetic undertones of Nehemiah 9:10 add an interesting dimension to the use of the exodus tradition in the penitential prayer under consideration. The

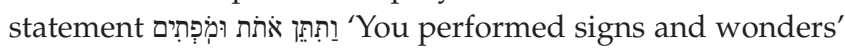
(v.10) carries prophetic undertones. Firstly, in the context of the Pentateuch, the reference to signs and wonders in Nehemiah 9:10 shows that the author of Nehemiah 9:6-37 probably borrowed the theme of Exodus from Exodus 7:3, 9 and Deuteronomy 6:22. Furthermore, in the context of the prophetic literature, a sign was given by a prophet to support the word of YHWH (cf. Joel 3:3; Ezek 12:6; Isa 8:18; Boda 1999:118). However, with respect to Nehemiah 9:11, Boda (1999) has argued that:

9:11b reveals the influence of the Song of Moses in Exodus 15, while incorporating other poetic descriptions connected with sea imagery. Of these images, the only one connected to the Exodus tradition was that found in Deutero-Isaiah. (p. 124)

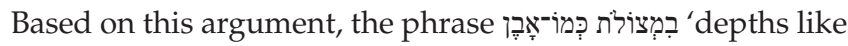
a stone' used in Exodus 15:5 is equally used in Nehemiah 9:11. In addition, the reference to Nehemiah 9:11 is reliant on Exodus 15:10. Concurring with Boda (1999:122-123), the author of Nehemiah 9:11 based the retelling of the Israel story on the Song of Moses in Exodus 15. On this point, first, the author of Nehemiah 9:11 depicts the deliverance of the Jews from Pharaoh, and second, makes reference to the Song of Moses with a view of conferring an authoritative status to the penitential prayer. Furthermore, the phrase 'mighty waters' (Isa 43:16) marks an allusion to the crossing of the Red Sea which is equally 
evident in Nehemiah 9:11. The allusion of the penitential prayer on the prophetic literature allows one to view Nehemiah 9:6-37 as set to cast a hopeful and prophetic imagination of a liberated community in postexilic Yehud.

Reasonably so, what we have in Nehemiah 9:6-37 is the reference to the suffering of the Jews in Egypt (cf. Exod 3:7; Deut 26:7), an allusion to the crisis at the Red Sea (cf. Exod $14: 10,15 \mathrm{a})$, the reference to the 'performed signs and wonders' (cf. Exod 7:3, 9; Deut 6:22; Neh 9:10), and an allusion to the Song of Moses (cf. Exod 15; Isa 43:16). That all these references and allusions seem to be made in the postexilic context when the Jews were slaves supports the view that the penitential prayer drew on authoritative texts to retell a story that articulated a statement of hope to the oppressed Jews. As will be argued below, firstly, it must be said though that the Jews in the postexilic period were the slaves of the Persian authorities; and secondly, the Judeans seem not to have been enslaved in the 'traditional' manner, but became exploited peasants (Brueggemann 2008:109). Although Nehemiah 9:6-37 presents a retelling of a story, it also seems that it is aimed at shaping the identity of the Jews in postexilic Yehud.

\section{Identity formation in Postexilic Yehud}

African theologians and philosophers have made a remarkable contribution to the topic of identity formation. For his part, Mbiti (1969) remarks:

\begin{abstract}
In traditional life, the individual does not and cannot exist alone except corporately. He owes this existence to other people, including those of past generations and his contemporaries. He is simply part of the whole. The community must therefore make, create, or produce the individual; for the individual depends on the corporate group ... (p. 108; cf. Ramose 1999:79)
\end{abstract}

The point made here is that a reliable portrait of an individual's identity is mirrored by the image and experiences of the community as a whole. The norms, values, and experiences that are embedded in the stories of African people constitute a critical role in the formation of the identity of individuals. As such, one is reminded of the contribution made by Jonker (2009:201-206) and Venter (2009:5) on the topic of identity formation, who in turn argued that both the social environment and the narratives of Israel's history shed light on the identity formation of the Jews in postexilic Yehud. Two issues are critical in the discussion of identity formation in postexilic Yehud:

- Contributions of the narratives to identity formation.

- Impact of social realities on identity formation.

\section{Contributions of the narratives to the identity formation of the Jewish community}

Balentine(2006:14)addresses theissueof theinstitutionalisation of penitential prayer in the postexilic period. He draws on
Werline's (2006:3-4) argument, who in turn proposes that the generalised and accepted use of motifs that define a community's identity in terms of its origins and distinguish the Jewish community from 'other' communities indicates a process of institutionalising penitential prayers. Said differently, the construction of the identity of the Jews in postexilic Yehud with the help of the penitential prayer conferred the authoritative status to the prayer.

Brueggemann (2008) has decisively argued that Nehemiah 9:6-37 functioned:

to recall the community to its singular identity, unmixed and uncompromised, committed to the one who is the source of identity and the only possible giver of 'new life' in the future. (p. 98, cf. Venter 2009:7)

The identity of the Jews that is embedded in Nehemiah 9:637 appears to be linked to the patriarch Abraham (vv.7-8), to the liberation of the Jews from Pharaoh (vv.9-15, 21), to the possession of the Promised Land (vv.22-25), to the caution about the consequence of disobedience to Yahweh - the exile (vv.16-21, 26-30)- and to the demise of the Babylonian exile (vv.31-37).

As Cezula (2013:127) observed, 'Nehemiah 9:2 reports that those of "Israelite descent" separated themselves from all foreigners, and stood and confessed their sins and the iniquities of their ancestors. It is interesting to note that the exiles are called those of Israelite descent' (cf. Fishbane 1985:114). This identification is linked to the figure of Abraham who is chosen by YHWH based on his faithfulness a sense of sacredness (cf. Neh 9:8). The image of sacredness which is expressed by the phrase 'holy seed' in the Holiness Code (cf. Lev 19:19), Deuteronomy (cf. Deut 30:6), as well as in Ezra-Nehemiah (cf. Ezra 9:2; Neh 9:2,8) presupposes that Ezra attempts to construct the Jewish national identity in Nehemiah 9:6-37 (Brett 2010:34). The idea of a holy people supports the view that what we have in Ezra 9:2, 8 is an articulation of the identity of the Judeans (probably the Babylonian exilic returnees) in postexilic Yehud. No doubt, the penitential prayer of Nehemiah 9:6-37, and more specifically by the reference to the figure of Abraham, identifies the Jews as a sacral community (Leuchter 2010:56; cf. Neh 8:13-18; 10).

At first glance, it appears that the existential problems of identity in postexilic Yehud are linked to the loss of king, temple, land, and independence to a point where the idea of the Torah is articulated in Nehemiah 9:6-37, while a text younger than Nehemiah 9, namely Daniel 9:4-19, holds the ideas of the land, king, and temple. However, the issue of the land is not entirely replaced by the Torah in the penitential prayer of Nehemiah 9:6-37, as the reference to the Promised Land is made in the text. The land is mentioned seven times in the prayer and four times in conjunction to the land promise made to the Patriarchs (cf. vv.9:8, 15, 22, 23, 24, 25, 35; Newman 1998:113). Based on the rise of the Torah and the authority given to texts that 
uphold the Torah as well as based on the emphasis on land, it becomes clear that the Torah became a symbol of identity for the Jews in the postexilic period; the promise of the land made to the patriarch, Abraham, becomes a symbol of identity.

Regarding the motif of exile embedded in Nehemiah 9:6-37, there seems to be no consensus among the Ezra-Nehemiah commentators. For instance, Williamson (2004:292-293) rejects the idea that a reference to the Babylonian exile is made in Nehemiah 9:6-37, while Venter (2009:5) supports the idea. Williamson based his argument on the observation that the captivity, exile, and return receive no mention in Nehemiah 9. This observation has also led him to argue that the addressees of the penitential prayer are the Jews who remained in the land, the so-called 'people of the land' (v.30). Although, the view that the captivity, exile, and return receive no mention in Nehemiah 9 is indisputable, there are however instances in the text where the Babylonian exile is presupposed. Firstly, an allusion to being handed to the enemies as a result of sin fits in the situation of exile (cf. vv.27-28) Secondly, the idea that there were people who were handed over to the people of the lands' in Nehemiah 9:30 suggest that the Babylonian exilic returnees were handed over to those who remained in in the land. In that case, an exilic situation is presupposed. Thus, on this point I would argue that although the exile is not explicitly mentioned in Nehemiah 9:6-37, the situation of exile is presupposed. The idea of exile forms part of the identity of the Jews in postexilic Yehud.

\section{Impact of social realities on the identity formation of the Jews in postexilic Yehud}

As mentioned earlier, a critical issue in the discourse of identity formation in postexilic Yehud is the impact that the social realities alluded to in ancient texts had on the formation of the identity of the Jews. The view that ancient texts are participants in the discourse on identity is appealing (Moffat 2013:23). Worthy of note is Jonker's (2009:201-206) argument that the 'notion that emphasizes the close relationship between the social environment within which a group exists, the textual resources that are available in the given culture, and the role that renewed textual construction plays in the process of identity formation' are critical in the discourse of identity construction in postexilic Yehud. This means that the Sitz-im-Leben, old traditions and the inner-biblical exegesis of ancient texts, as participants, shaped the identity of the Jews in the postexilic context. Put differently, Moffat (2013:28) says, 'For both exiles and Judean inhabitants, kinship and traditions of the past, along with imperialism and resistance to imperialising forces, influenced the identities they forged'. This statement further confirms the influence that the context from which Nehemiah 9:6-37 emerged had on the formation of the identity of the Jews in postexilic Yehud.

The argument that the addressees of Nehemiah 9:6-37 experienced socio-economic injustice which widened the gap between the poor and the wealthy shed light to the identity of the Jews. As a collective, the addressees of the Jews in postexilic Yehud were an unequal community that was divided on economic and class lines. That there was disproportional benefit from land ownership confirms the view of an unequal community. Furthermore, the addressees of Nehemiah 9:6-37 may be identified as a community that worked on the farms under harsh realities and subsequently did not receive what was rightfully due to them. The text regards such a community as being slaves. For instance, Brueggemann argues that the Jews who were treated as slaves in Babylonia were equally treated as slaves by the Persian authorities in the postexilic period (Brueggemann 2008:109; cf. Brueggemann 1997:115; Rugwiji 2013:46; Usue 2007:843). Based on v. 33, he explains Ezra's action in the following manner:

He describes for God the exploited status of the Jews in Jerusalem at the hands of the Persians... For all of the generosity and support of Artaxerxes for Nehemiah, the Persians are effective tax collectors. They exploited the colony of Yehud so vigorously that Ezra can say, 'we are slaves'... The Jews are back at work in the homeland, but are exploited peasants. (Brueggemann 2008:109; cf. Cezula 2013:91; Moffat 2013:49)

Based on this explanation as well as on the textual evident of Nehemiah 9:6-37, and more specifically based on the plural absolute noun עִבְבדִים 'we are slaves', there is no doubt that the Jews were viewed as slaves during the postexilic period.

\section{Conclusion}

In conclusion, this paper submits the penitential prayer of Nehemiah 9:6-37 received an authoritative status in postexilic Yehud because the prayer presented a retelling of the story of Israel and it shaped the identity of the Jews. It has been argued here that Nehemiah 9:6-37 was set to cast a hopeful and prophetic imagination of a liberated community in postexilic Yehud. In other words, the penitential prayer of Nehemiah 9:6-37 drew on authoritative texts to articulate a statement of hope to the oppressed Jews in postexilic Yehud. Also, because the penitential prayer of Nehemiah 9:6-37 challenged the sins of the addressees and drew on the traditions that had prophetic undertones, the prayer may be viewed as set to offer a prophetic imagination of a liberated (delivered) community in the postexilic period.

\section{Acknowledgements Competing interests}

The author declares that he has no financial or personal relationships which may have inappropriately influenced him in writing this article.

\section{References}

Balentine, S.E., 2006, 'I was ready to be sought out by those who did not Ask', in M.J. Boda, D.K. Falk \& R.A. Werline (eds.), Seeking the favor of God, 1. The origins of Penitential Prayer in Second Temple Judaism, pp. 1-20, Society of Biblical Literature, Atlanta, GA. 
Boda, M.J., 1999, Praying the tradition: The origin and use of tradition in Nehemiah 9 W. de Gruyter, Berlin. Beihefte zur Zeitschrift für die alttestamentliche Wissenschaft 277.

Brett, M.G., 2010, 'National identity as commentary and as metacommentary', in L. Jonker (ed.), Historiography and identity (re)formulation in Second Temple historiographical literature, pp. 29-40, T \& T Clark International, New York.

Brueggemann, W., 1997, Cadences of home: Preaching among exiles, Westminster John Knox Press, Louisville, KY.

Brueggemann, W., 2003, An introduction to the Old Testament: The canon and Christian imagination, Westminster John Knox Press, Louisville, KY.

Brueggemann, W., 2008, Great prayers of the Old Testament, Westminster John Knox Press, Louisville, KY.

Cezula, N., 2013, 'Identity formation and community solidarity: Second Temple historiographies in discourse with (South) African theologies of reconstruction',
Unpublished PhD thesis, Department of Old and New Testament, University of Unpublished PhD thesis, D

Clines, D.J.A., 1989, 'The force of the text: A response to Tamara C. Eskenazi's "Ezra-Nehemiah: From text to actuality", in J.C. Exum (ed.), Signs and wonders: Biblical texts in literary focus, pp. 199-216, Scholars Press, Atlanta, GA. [Semeia Studies 18]

Falk, D.K., 2007, 'Scriptural inspiration for Penitential Prayer in the Dead Sea Scrolls', in M.J. Boda, D.K. Falk \& R.A. Werline (eds.), Seeking the favor of God. 2. The development of Penitential Prayer in Second Temple Judaism, pp. 127-157, Society of Biblical Literature, Atlanta, GA.

Fishbane, M., 1985, Biblical interpretation in Ancient Israel, Clarendon Press, Oxford.

Jonker, L., 2009, 'Textual identities in the Books of Chronicles: The case of Jehoram's history', in G.N. Knoppers \& K.A. Ristau (eds.), Community identity in Judean historiography: Biblical and comparative perspectives, pp. 197-217, Eisenbrauns, Winona Lake, IN.

Klein, R.W., 2004, 'A response', in G.N. Knoppers (ed.), Revisiting the composition of Ezra-Nehemiah: In conversation with Jacob Wright's rebuilding identity: The Nehemiah memoir and its earliest readers, pp. 21-27, W. de Gruyter, Berlin. Beihefte für die alttestamentliche Wissenschaft 348.

Leuchter, M., 2010, 'Coming to terms with Ezra's many identities in Ezra-Nehemiah', in L. Jonker (ed.), Historiography and identity (re)formulation in second temple historiographical literature, pp. 41-64, T \& T Clark International, New York.

Mbiti, J.S., 1969, African religions and philosophy, Heinemann, Oxford.
Moffat, D.P., 2013, Ezra's social drama: Identity formation, marriage and social conflict in Ezra 9 and 10, Bloomsbury, New York.

Newman, J.H., 1998, 'Nehemiah 9 and the scripturalization of prayer in the Second Temple period', in C.A. Evans \& J.A. Sanders (eds.), The function of scripture in early Jewish and Christian tradition, pp. 112-123, Sheffield Academic Press, Sheffield.

Newman, J.H., 1999, Praying by the book: The scripturalization of prayer in Second Temple Judaism, Scholars Press, Atlanta, GA. Society of Biblical Literature: Early Judaism and its literature, 14

Nihan, C., 2010, 'Moses and the prophets: Deuteronomy 18 and the emergence of the Pentateuch as Torah', Svensk Exegetisk Arsbok 75, 21-55.

Otto, E., 2013, 'Torah and prophecy: A debate of changing identities', Verbum et Ecclesia 34(2), 1-5.

Ramose, M.B., 1999, African philosophy through Ubuntu, Mond Books, Harare.

Rugwiji, T., 2013, 'Appropriating Judean post-exilic literature in a postcolonial discourse - A case for Zimbabwe', Unpublished PhD thesis, Department of Biblical and Ancient Studies, University of South Africa, Pretoria.

Said, E.W., 2000, Reflections on exile and other essays, Harvard University Press, Cambridge, MA.

Schmid, K., 2007, 'The late Persian formation of the Torah: Observations on Deuteronomy 34', in O. Lipschits, G.N. Knoppers \& R. Albertz (eds.), Judah and the Judeans in the fourth century B.C.E., pp. 236-245, Eisenbrauns, Winona Lake, IN.

Throntveit, M.A., 1992, Ezra-Nehemiah, John Knox Press, Louisville, KY. [Interpretation]

Usue, E.O., 2007, 'Restoration or desperation in Ezra and Nehemiah? Implications for Africa', Old Testament Essays 20(3), 830-846.

Venter, P.M., 2002, 'The connection between wisdom literature, apocalypses and canon', Old Testament Essays 15(2), 470-488.

Venter, P.M., 2009, 'Canon, intertextuality and history in Nehemiah 7:72b-10:40', HTS Teologiese Studies/Theological Studies 65(1), 1-8.

Werline, R.A., 1998, Penitential Prayer in Second Temple Judaism: The development of a religious institution, Scholar Press, Atlanta, GA.

Werline, R.A., 2006, 'Defining Penitential Prayer', in M.J. Boda, D.K. Falk \& R.A. Werline (eds.), Seeking the favor of God, 1. The origins of Penitential Prayer in Second Temple Judaism, pp. xiii-xvii, Society of Biblical Literature, Atlanta, GA.

Williamson, H.G.M., 2004, Studies in Persian period history and historiography, Mohr Siebeck, Tübingen. 